\title{
UK denies responsibility for Scandinavian acid rain
}

THE government of Norway, downwind of the high chimneys through which Britain discharges sulphur dioxide and other gases from its power stations, is not in the least impressed by the British decision last week to fit desulphurization plants to three of the offending stations. Announced in London while British Prime Minister Mrs Margaret Thatcher was in Norway visiting her opposite number, Mrs Gro Harlem Brundtland, the decision was described by a Norwegian environment ministry spokesman as a "slap in the face" for Norway, which had been expecting a much greater gesture.

Yet according to Lord Marshall, chairman of Britain's principal emitter, the Central Electricity Generating Board (CEGB), the British decision was based on "new research" on acid lakes and streams in Scandinavia and there is at last a "reasonably sound scientific basis" for CEGB actions. These aim for a reduction of about 10 per cent in CEGB sulphur emissions by the year 2000. Scientists led by the Swedish Environmental Protection Board say 90 per cent is necessary. The CEGB plans to achieve such cuts, but only by 2020 , when existing coal-fired plants will have gone, to be replaced by new lowsulphur plants or nuclear power stations. This will be too late, say the Scandinavians, who claim for example that of $33,000 \mathrm{~km}^{2}$ of southern Norway now affected by acid rain some $13,000 \mathrm{~km}^{2}$, seven major salmon fisheries are now devoid of fish, and 2,500-6,000 Swedish lakes are also affected.

The research of interest to the CEGB includes some of the results from the joint research group of the Royal Society, the Royal Swedish Academy of Sciences, and the Norwegian Academy of Science and Letters (funded by the board and by British Coal), whose first report is due next year, and international work on sulphur dioxide transport. But the Scandinavian view is that the British generating board is making its "small" move towards desulphurization only because the new findings can be interpreted to reduce and limit the board's culpability. Among these findings, improved atmospheric models have halved the degree to which acid inputs in Scandinavia can be traced to British sources, and new soil measurements have reduced estimates of the likely improvements to be gained from any immediate reduction in sulphur deposition. Environmentalists and some Scandinavian experts, however, dispute the board's interpretation of the data.
Of the two main sets of results, the transport figures may prove the least conish contribution to acid deposition in Norway as a whole is only 8.5 per cent of total depositions, less than Norway's own contribution, says the board. Anton Eliassen of the Norwegian Meteorological Institute in Oslo agrees. Eliassen himself made a major contribution to the study, which is part of the United Nations Economic Commission for Europe pollution monitoring programme (EMEP). The fall in the British contribution ( 30 per cent was the consensus a few years ago) is the result of an improved model using a muchreduced estimate of the dry deposition rates of sulphur dioxide on sub-freezing surfaces and snow, says Eliassen. These have been measured to be four times lower in mid-Norway in mid-winter than previously assumed. The rate of conversion of sulphur dioxide to sulphate is also now known to be halved in mid-winter, and five times the minimum in mid summer, and these effects have been included in the new transport model. With a winter peak in sulphur dioxide production, the result is that sulphur dioxide is transported on average much farther before deposition than earlier models predicted. But the resulting Norway-wide average for British depositions on the country of 8.5 per cent of the total obscures the fact, says Eliassen, that in the most sensitive, soft-water region of southwestern Norway Britain contributes 16 per cent, compared to a local contribution of just 3 per cent.

Forty-five per cent of the sulphur detroversial. The directly attributable Brit-

positions in the region are "unattributable'; that is, they come from parcels of air which have been over the Atlantic for more than four days, beyond the limit of the EMEP mode'l projections. What part of this does Britain contribute? Environmentalists suggest as much as half. But there are other large emitters in Europe, and even America, that must contribute to the sulphur dioxide over the Atlantic, and possible biological sources in the occans. The new EMEP model allows for external inpuis into the European area, however. and only requires some 14 per cent of additional sulphur. (No more than 10 per cent of this is likely to come from the USA, according to Eliassen.) The rest, then, must be recirculated Furopean emissions, and a considerable fraction of that is likely to be British. Nevertheless it remained possible for Mrs Thatcher to claim that the proven British impact on Norway (as a whole) was small.

The second set of results to please the British generating board concern the quantities of sulphur that already exist in Scandinavian soils, whether or not it came from anthropogenic sources, and measurements of the effect of the deacidification of rain over a trial catchment area for 18 months. According to Peter Chester, chief environmental scientist of the board, in one Norwegian catchment (Risdalsheia) the reservoir of soil sulphur exceeded the amount of water soluble sulphate $100-$ fold, and in another (Gardsjon) 20 -fold. The chemical nature of this sulphur is not certain, says Chester, but if it is mobilized - and there is evidence, he claims, that it can be mobilized by nitric acid flushes from biological decay after forest clearance - then it represents a sulphate reservoir amounting to decades of sulphur deposition at present rates. So, Chester argues, there is no point in reducing sulphur emissions rapidly, as this reservoir will continue to have its effect for years to come.

Robert Walgate

Prime Ministers Brundtland (Norway) and Thatcher (Britain) exchanging a few acid words?

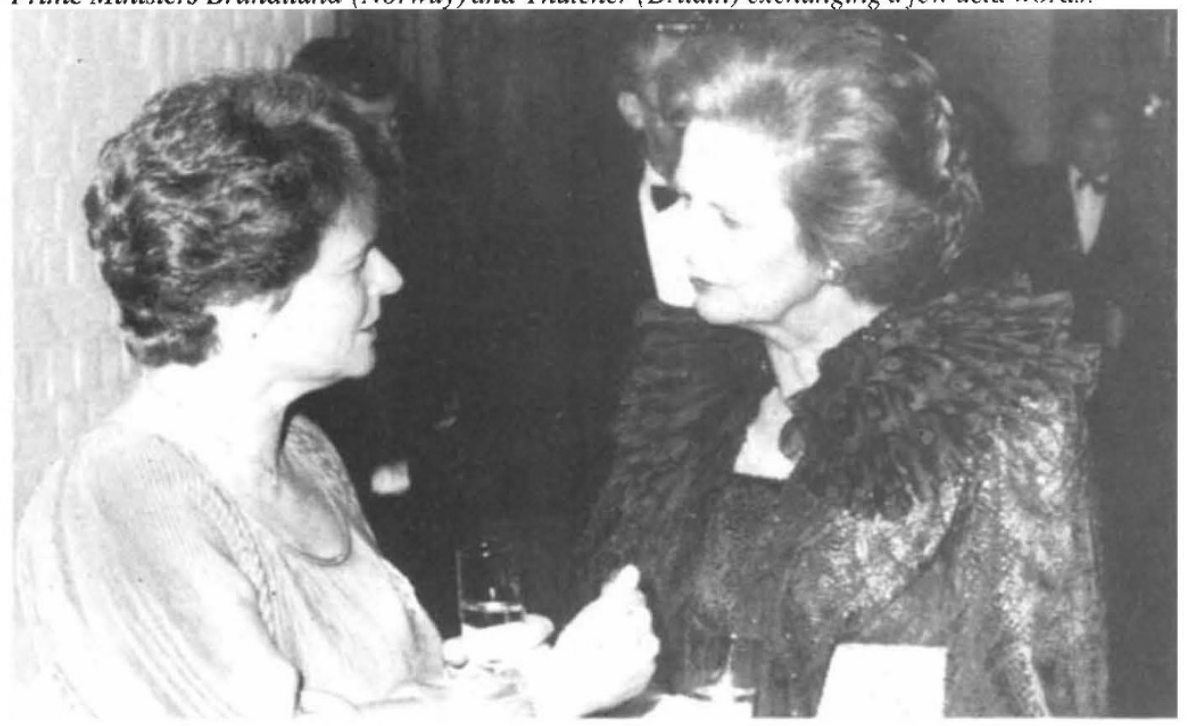

